\title{
Association of Soil Chemical and Physical Properties with Pythium Species Diversity, Community Composition, and Disease Incidence
}

\author{
K. D. Broders, M. W. Wallhead, G. D. Austin, P. E. Lipps, P. A. Paul, R. W. Mullen, and A. E. Dorrance
}

First, second, third, fourth, fifth, and seventh authors: Department of Plant Pathology and sixth author: School of Natural Resources, The Ohio State University, Wooster 44691.

Accepted for publication 31 March 2009.

\begin{abstract}
Broders, K. D., Wallhead, M. W., Austin, G. D., Lipps, P. E., Paul, P. A., Mullen, R. W., and Dorrance, A. E. 2009. Association of soil chemical and physical properties with Pythium species diversity, community composition, and disease incidence. Phytopathology 99:957-967.

A high-throughput baiting and identification process identified more than 7,000 isolates of Pythium from 88 locations in Ohio. Isolates were identified using direct-colony polymerase chain reaction followed by single-strand conformational polymorphism, and communities were assembled using the Jaccard similarity coefficient and cluster analysis. Both univariate and multivariate statistics were used to evaluate differences in soil properties between communities, and canonical discriminant analysis (CDA) was used to assess the strength of the association of soil variables within communities from 83 of the locations. In all, 21 species
\end{abstract}

ABSTRACT of Pythium were identified but only 6 were recovered from $>40 \%$ of the locations. Five communities were formed using the cluster analysis, and significant differences were observed in disease incidence, as well as soil $\mathrm{pH}$, calcium, magnesium, and cation exchange capacity between communities. Stepwise multiple discriminant analysis and CDA identified $\mathrm{pH}$, calcium, magnesium, and field capacity as contributing the most to the separation of the five Pythium communities. There was a strong association between abiotic soil components and the structure of Pythium communities, as well as diversity of Pythium spp. collected from agronomic production fields in Ohio.

Additional keywords: P. dissotocum, P. inflatum, P. irregulare, P. torulosum, P. ultimum, richness, seedling disease, soil texture.
Pythium spp. are frequently associated with seed and seedling diseases, and have been commonly isolated from corn (36) and soybean $(4,13,37)$ early in the season when the soils are predominantly moist and cool. Infections by species of Pythium may result in both pre- and post-emergence damping-off, but some surviving plants may be able to grow and produce a root system. These nonlethal infections generally lead to reduced root and shoot growth, resulting in reduced plant vigor and, consequently, yield. Several Pythium spp. may be isolated from a single piece of root tissue or from the soil surrounding the root tissue. This makes it difficult to attribute the cause of the disease to an individual species, because both pathogens and saprophytes may be recovered. Species of Pythium are also known to range in pathogenicity on soybean $(3,11,48)$, corn $(3,8,36)$, and wheat (15). This complicates the development of effective seedling disease management strategies, because multiple species must be managed.

Fungicide active ingredients used to treat soybean and corn seed have changed in recent years; however, emergence problems continue to plague some growers in certain production regions of Ohio. In a number of earlier studies in Ohio, Pythium catenulatum, $P$. irregulare, $P$. paroecandrum, $P$. splendens, and $P$. torulosum were isolated and identified from soybean using a soil baiting technique (11), and $P$. arrhenomanes, $P$. dissotocum, $P$. graminicola, $P$. ultimum, and $P$. torulosum from corn $(27,36)$. During spring 2004 and 2005, isolations were made from

Corresponding author: A. E. Dorrance; E-mail address: dorrance.1@ osu.edu

doi:10.1094/PHYTO-99-8-0957

(c) 2009 The American Phytopathological Society diseased corn and soybean seed and seedlings collected in Ohio from fields with a history of stand establishment problems (3). During the 2 years, 12 species of Pythium were recovered, including a new species isolated from soybean seedlings, $P$. delawarii (2). This survey of problem fields also provided the first report of $P$. attrantheridium as a pathogen of both corn and soybean, the first report of $P$. dissotocum as a pathogen of soybean, and the first report of $P$. inflatum as a seed and seedling pathogen of corn and soybean in North America (3).

One of the major challenges of managing diseases caused by more than one species of Pythium is properly identifying all the species associated with the disease. Due to the time and different conditions required for sporangia and oospore development, correct identification of Pythium spp. via morphology has hampered attempts to complete large-scale surveys to determine how many different species are present in a field, which species are the most abundant, and which are the most pathogenic. Single-strand conformational polymorphism (SSCP) is a method that uses the internal transcribed spacer (ITS) region of the ribosomal DNA to identify individual species of Pythium (22-24). This technique is more commonly used to detect single base pair mutations (38) but has been adapted to identify individual fungal and oomycete species $(22,23)$. During SSCP, the polymerase chain reaction (PCR) product is denatured and the single-strand DNA molecules fold into complex three-dimensional structures as a result of intrastrand base pairing. Therefore, single strands of equal length but different sequence can vary considerably in electrophoretic mobility as a result of the looping and compaction caused by intrastrand pairing. When SSCP products are run on a polyacrylamide gel, each species produces a specific banding pattern. SSCP combined with direct-colony (DC)-PCR has proven to be quick, inexpensive, and sensitive (23), and has been adapted and 
confirmed on Pythium spp. recovered from diseased corn and soybean seedlings. The advantage of DC-PCR is that mycelia from an isolate can be used directly in the PCR reaction, foregoing the timely process of extracting DNA, and the amplicon is also suitable for sequencing after a purification step to remove PCR reaction components.

Disease of corn and soybean caused by Pythium spp. tends to be patchy, both from field to field and within a field; and, for specific areas of some fields, disease is an annual occurrence. Interestingly, it is not always the typically poorly drained, lowlying areas of the field that may be affected. The patchiness of disease may be due, in part, to variation in soil types found in Ohio as well as the Pythium communities present in those soils. A large portion of the crop production region is characterized by soil with a high lime content, left as a result of glacial drift during the Wisconsonian era (5). In the southwest region of the state, soils were deposited during the Illinoisan era $(\approx 300,000$ to 130,000 years ago); thus, these soils are older and tend to be more weathered, less fertile, and generally have $<3 \%$ organic matter (OM) (Fig. 1). The Northwest region of the state is composed of soils left as the result of Lake Erie receding to its current size, and generally has higher OM, higher percentage of clay in the topsoil, and a high water table that may be $<1$ foot below the surface (Fig.

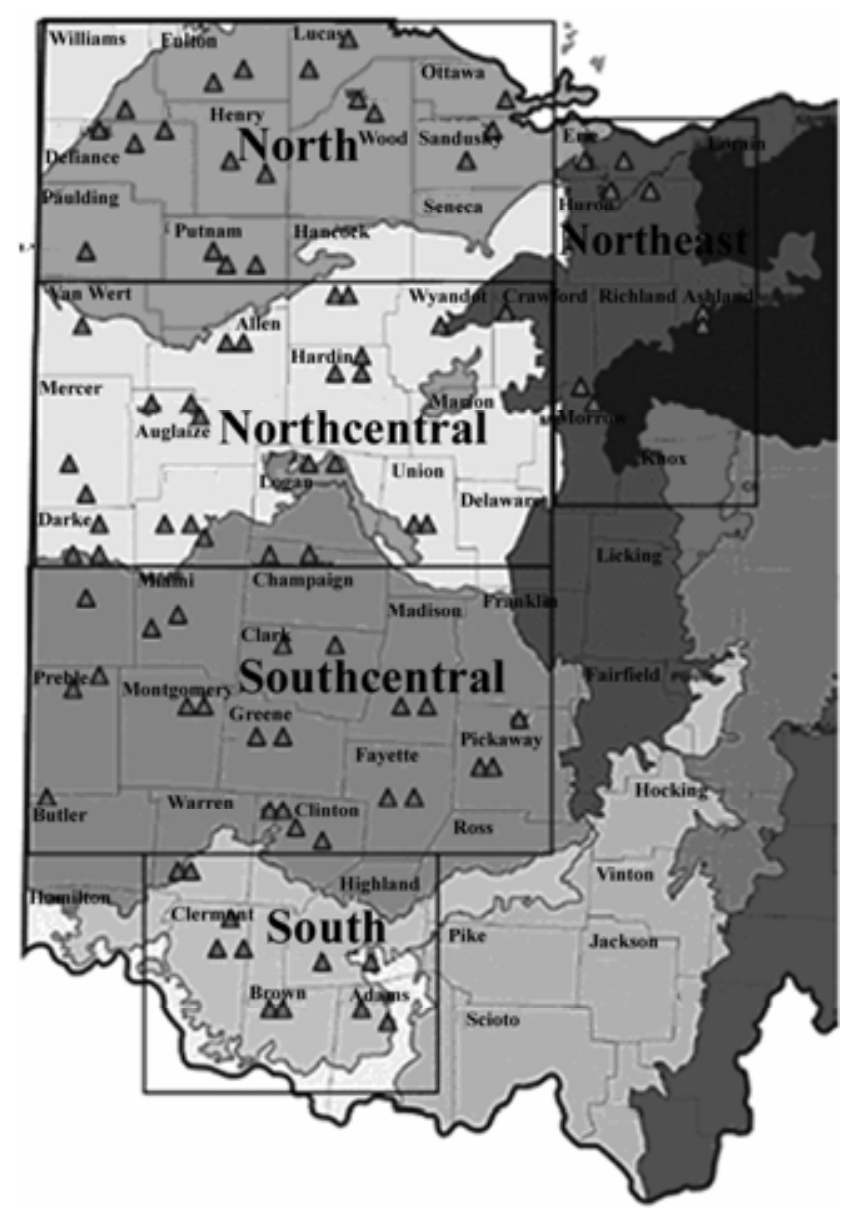

Fig. 1. Soil region and county map of the corn and soybean production region of Ohio. The study area was divided in to five large geographic regions based on GPS coordinates and natural soil regions. The North region consisted of mostly Hoytville-Nappanee-Paulding-Toledo soil series. The Northcentral region consisted of mostly Blount-Pewano-Glynwood soil series. The Northeast region consisted of Conotton-Conneaut-Allis, Bennington-CardingtonCenterberg, and Mahoning-Canfield-Ritman-Chili soil series. The Southcentral regions consisted mostly of Miamian-Kokomo-Eldean soil series. The Southern region consisted mostly of Clermont-Rossmoyne-Avonberg-Cincinnati soil series. Soil regions were designated by the Ohio Department of Natural Resources. Triangles represent sampling sites.
1). The Northcentral and Southcentral regions have a coarsertextured soil providing better drainage than most soils of the Northwest region. Consequently, soil types among fields where corn and soybean are grown may vary considerably both from north to south and within a few square kilometers. The diversity of soil types found in Ohio may provide insight into how composition of Pythium communities, species diversity, and disease incidence are affected by abiotic soil factors.

A more comprehensive evaluation of the Pythium communities existing in agricultural soils is needed to determine whether the communities are distributed uniformly across the state or whether they are specific to a region or soil class. Based on these results, it may be possible to determine whether soil physical or chemical properties may favor occurrence of a specific community of species. This knowledge may facilitate the understanding of which soil properties may favor one Pythium sp. over another or favor a larger diversity of Pythium spp. The objectives of this project were to (i) identify the Pythium spp. collected from 88 locations across the five major soil regions where corn and soybean are primarily grown in Ohio, (ii) characterize the Pythium communities present in agricultural production fields in Ohio and determine the soil properties most frequently associated with these communities, and (iii) evaluate the relationship between disease incidence and Pythium community composition, species diversity, and soil properties.

\section{MATERIALS AND METHODS}

Site description and sampling strategy. Soil was collected from 88 locations representing 42 counties in the corn and soybean production regions of Ohio between 20 June and 19 July 2006 and 7 and 25 June 2007 (Fig. 1). A stratified random sampling technique was used (43) and GPS coordinates were recorded for each location. The study area was divided into five strata based on the five major soil regions, and then fields within each stratum were further stratified based on topography and soil type. The five soil regions (North, Northeast, Northcentral, Southcentral, and South) were inferred from the soil region map assembled by the Ohio Department of Natural Resources (Fig. 1). Fields with a history of severe and moderate levels of emergence problems and fields with no history of disease were identified with the assistance of county extension educators, crop advisors, and producers. At six sites per field, two soil cores $(10 \mathrm{~cm}$ in diameter by $15 \mathrm{~cm}$ deep) were collected. A W-shaped sampling pattern was used to select the six sites within each field and the sites were generally $25 \mathrm{~m}$ apart. Attempts were made to get a representative sample of the following: all soil types found in the primary corn and soybean production region; differences in topography of each field; and approximately equal numbers of fields with severe, moderate, and no history of stand establishment issues.

Isolation and identification of Pythium spp. Soil from each site within each field was air dried, ground, and placed into three $15-\mathrm{cm}$ pots. The pots were saturated for $24 \mathrm{~h}$, allowed to drain, and incubated at $16^{\circ} \mathrm{C}$ for 14 days to promote development and maturation of Pythium spp. survival structures and suppress activity of Phytophthora sojae in order to limit its effect on soybean disease incidence data. The soil was baited using corn hybrid LG2540 and soybean cvs. Sloan and Kottman according to the procedure described by Dorrance et al. (11). Briefly, 15 untreated seeds were planted per pot, with each cultivar being planted in a separate pot. Seed were placed on top of the soil and then covered with course vermiculite. The baited soils were placed in a growth chamber set at $18 \pm 1^{\circ} \mathrm{C}$ with a 13 -h photoperiod. Five days after planting, soils were saturated for $24 \mathrm{~h}$ to enhance disease development. Four days after the flooding treatment (10 days post-planting), all seed and seedlings were recovered and rinsed with tap water, and tissue with expanding 
brown lesions was plated on PIBNC, an oomycete-specific medium $(10,40)$. Plant tissue from nine different plants of each of the two cultivars and one hybrid at each of the six sites were sampled for a total of 162 pieces of plant tissue per location. Disease incidence was also recorded for each location and was calculated as the number of infected plants/the number of plants sampled $\times 100$. The tissue sampled from each plant focused primarily on lesions from the main root and feeder roots; however, lesions occurring on the seed, stem, cotyledons, and coleoptiles were also sampled. The presence of Pythium spp. was determined by the type of mycelial growth on PIBNC from the piece of plated plant tissue. To ensure that all isolates were Pythium, they were evaluated by colony morphology and mycelial growth on potato-carrot agar (PCA) (48). In addition, $\approx 5 \%$ of the total number of isolates $(<350)$ recovered were randomly selected along with those isolates with unique banding patterns in the SSCP gels and were further examined in grass-blade culture (48). Isolates were hyphal tip transferred to PCA vials and stored at $10^{\circ} \mathrm{C}$ until evaluated.

Pythium isolates were identified to species using DC-PCR and SSCP $(23,24)$, ITS sequence, and morphology using standard keys $(44,45)$. For DC-PCR, a 50- $\mu$ l reaction consisting of $10 \mu \mathrm{l}$ of $5 \times$ Green GoTaq Reaction buffer (Promega Corp., Madison, WI), $5 \mu \mathrm{l}$ of $25 \mathrm{mM} \mathrm{MgCl}_{2}, 3 \mu \mathrm{l}$ containing $1.3 \mathrm{mM}$ each $\mathrm{dNTP}, 0.5 \mu \mathrm{l}$ of GoTaq Taq polymerase (Promega Corp.), $5 \mu$ l each of a 5-pmol concentration of primers ITS6 (5'-GAAGGTGAAGTCGTAACAAGG-3') and ITS7 (5'-AGCGTTCTTCATCGATGTGC-3'), and $21.5 \mu \mathrm{l}$ of sterile deionized water. A sterile toothpick was used to collect $\approx 1 \mathrm{~mm}^{3}$ of mycelia by gently touching the toothpick tip along the growing edge of a 2- to 4-day-old Pythium sp. culture grown on PCA. The mycelia were then added directly to the reaction. The primer pair ITS6 and ITS7 amplified an $\approx 300$-bp portion of the ITS1 region of ribosomal DNA. Most locations had $<96$ isolates; therefore, the DC-PCRs of all isolates from a single location were included in a 96-well plate. For the SSCP analysis, $2 \mu \mathrm{l}$ of the DC-PCR was added to $8 \mu \mathrm{l}$ of denaturing buffer $(20 \mu \mathrm{l}$ of $5 \mathrm{M} \mathrm{NaOH}, 9.5 \mathrm{ml}$ of formamide, $5 \mathrm{mg}$ of bromophenol blue, and $\mathrm{dH}_{2} \mathrm{O}$ to $10 \mathrm{ml}$ ) and denatured for $5 \mathrm{~min}$ at $95^{\circ} \mathrm{C}$, and then $5 \mu \mathrm{l}$ was loaded per well in an $8 \%$ nondenaturing polyacrylamide gel, and DNA visualized by silver staining (Fig. 2). Gels were scanned and converted into digital images. These images were then used to assist in identification of individual banding patterns in relation to the standards and the DNA ladder (Fig. 2). The DNA ladder consisted of $2 \mu \mathrm{l}$ of $0.2 \mu \mathrm{M}$ X174 DNA/HaeII ladder, and $37 \mu \mathrm{l}$ of denaturing buffer. An aliquot of $4 \mu \mathrm{l}$ of this mix was loaded per lane after heat denaturation. The MEGA-Gel vertical electrophoresis system (C.B.S. Scientific Co., Del Mar, CA) was used for SSCP analysis. This system has the capacity to run two 100-well acrylamide gels, allowing for the simultaneous identification of up to 192 isolates of Pythium. Sixteen species previously identified by morphology and sequence data were included on each gel and used as a standard set of isolates for comparison to all unknown isolates. To confirm the identity on the SSCP gels, at least two to four amplicons of the DC-PCR from each gel representing different banding patters were sequenced. In addition, if a banding pattern was observed that was not similar to any of the 16 standards, then 37 Pythium irregulare isolates from 27 locations (to identify if there was more than one genotype of $P$. irregulare present in the study area) (15) and 13 and 12 isolates of $P$. ultimum var. sporangiiferum and P. ultimum var. ultimum, respectively, were also sequenced. The DC-PCR product of each isolate was purified using Qiaquick spin columns (Qiagen, Inc., Valencia, CA), and sequenced. Sequencing was done at the Molecular and Cellular Imaging Center at the Ohio Agricultural Research and Development Center (OARDC, Wooster). Sequences were aligned and edited using Sequencher 4.6 (Gene Codes Corporation, Ann Arbor, MI) and compared with known sequences in our collection as well as sequences deposited in the
National Center for Biotechnology Information nonredundant database to confirm identity.

Soil analyses. Soil samples were evaluated for both physical and chemical properties. Chemical properties evaluated were $\mathrm{pH}$; available phosphorus, exchangeable calcium, potassium, and magnesium; cation exchange capacity (CEC), and OM content. Phosphorus, potassium, calcium, and magnesium were measured as $\mu \mathrm{g} / \mathrm{g}, \mathrm{CEC}$ was measured as meq/100 $\mathrm{g}$, and OM was measured as the percent weight loss on ignition. Chemical properties were analyzed by the Service Testing and Research laboratory on the OARDC campus in Wooster. Physical properties evaluated were water holding capacity measured as field capacity and soil texture measured as the percent sand, silt, and clay of each sample. Field capacity was calculated using the pressure plate method outlined by Tan (42) to give the percentage of water at field capacity. Soil texture, as the percent clay, sand, and silt, was measured using the hydrometer method (42). Each location was classified based on the soil texture (i.e., $30 \%$ clay, $40 \%$ silt, and $30 \%$ sand is a clay loam according to the United States Department of Agriculture guide for soil textural classification).

Statistical analyses. The frequency of occurrence of each species was calculated as the number of sites that contained that species/total number of sites $\times 100$. Species richness and abundance was given as the total number of species and total number of isolates of each species recovered at each location, respectively. Species abundance data were graphed using a rank/ abundance plot and PROC GLM was used to fit a species abundance model to these plots. Species diversity of each location was calculated using the Shannon index, such that $\mathrm{H}^{\prime}=\Sigma p i \ln p i$, where $\mathrm{H}^{\prime}$ is the species diversity score and $p i$ is the proportion of individuals in the $i$ th species (25). Disease incidence was calculated as the number of infected plants/total number of plant sampled $\times 100$. Relationships among species diversity and disease incidence, and soil chemical and physical properties, were evaluated by regression analysis and Spearman correlation analysis (SAS version 9.1; SAS institute, Cary, NC). A principal component analysis was also carried out in SAS using all 11 chemical and physical soil properties to determine which properties or combination of properties accounted for the majority of variability in disease incidence between locations.

Hierarchical cluster analysis, using Jaccard's similarity index (JI), was used to group locations together based on species composition (34). Each of the 21 species was designated 1 for presence and 0 for absence for each location. The Jaccard similarity coefficient was calculated for each pairwise combination of sampling sites, such that $\mathrm{JI}=c /(a+b+c)$, where $a=$ the number of species unique to site $\mathrm{A}, b=$ the number of species unique to site $\mathrm{B}$, and $c=$ the number of species found in both site $\mathrm{A}$ and $\mathrm{B}$ (34). Therefore, sites that have more species in common are more similar and sites that have fewer species in common and more unique species will be more dissimilar. SAS (version 9.1) was used to calculate Jaccard similarity coefficients for each pairwise combination and then used to create a dendrogram of the similarity coefficients using the Ward's minimum variance method.

Canonical discriminant analysis (CDA) was used to assess the strength of the association of soil variables within the five Pythium communities defined in the cluster analysis. Standardized canonical coefficients and canonical correlation coefficients were used to evaluate the significance of individual soil properties. in total, 11 soil variables were evaluated. However, the discriminatory power could substantially decrease if too many variables were used for the discriminant analysis; therefore, the greater the number of variable $p$, the bigger the sample needed to achieve the same level of precision (19). To provide more descriptive results, the variable selection procedure PROC STEPDISC was used to eliminate variables that did not provide additional information or were redundant. 


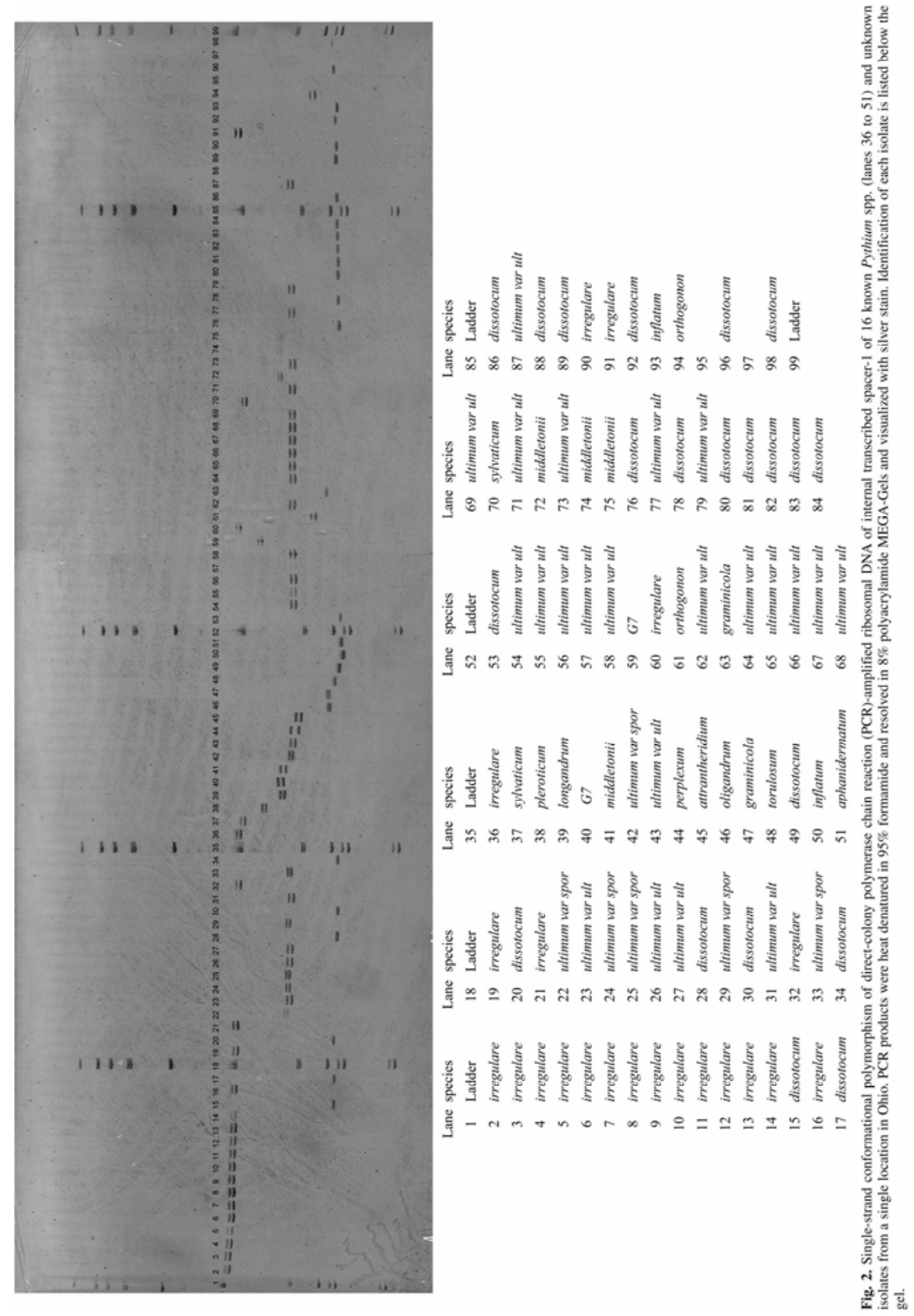


The PROC GLM function in SAS (version 9.1) was used to determine the difference in species diversity and disease incidence between the five soil classes. Some soil classes that had fewer representatives were combined to form a single larger soil class. The locations that were classified as silty-clay, silty-clayloam, and silt-loam were combined and are herein referred to as the soil class high silt. Additionally, the soil classes sandy-clay, sandy-clay-loam, and sandy-loam were combined and are herein referred to as high sand. Soil classes clay, clay loam, loam, high silt, and high sand represented groups and were composed of 18 , $31,13,10$, and 8 locations, respectively, which represent replication in the analysis.

\section{RESULTS}

In total, 7,064 isolates of Pythium representing 21 different species were recovered from the 88 locations sampled using a high-throughput system of soil baiting, DC-PCR, and SSCP (Fig. 2). P. irregulare, $P$. inflatum, and $P$. torulosum were the species most frequently recovered and occurred at $>70 \%$ of the locations (Fig. 3). P. ultimum var. ultimum, P. ultimum var. sporangiiferum, and $P$. dissotocum were recovered from 47 to $54 \%$ of the locations while P. pleroticum was found in $39 \%$ of the locations (Fig. 3). One unidentified species, designated as group 7 (G7), was recovered from $30 \%$ of the locations. The isolates of this species had a radiate to rosette growth pattern in PCA, with usually terminal oogonia, plerotic oospores, diclinous and monoclinous antheridia, and mycelial growth of 7 to $10 \mathrm{~mm}$ per day. Sporangia were not observed in grass blade culture but sequence data of the ITS1-5.8S-ITS2 region of the ribosomal DNA was similar to $P$. acrogynum and $P$. hypogynum. There were 13 Pythium spp. recovered from $<10 \%$ of the locations: $P$. aphanidermatum, $P$. arrhenomanes, $P$ attrantheridium, $P$. graminicola, $P$. hypogynum, $P$. longandrum, $P$. middletonii, $P$. oligandrum, $P$. orthogonon, $P$. parvum, $P$. perplexum, $P$. sylvaticum, and $P$. vanterpoolii (Fig. 3 ).

Two different sequences of the 330-bp region for the 37 isolates of $P$. irregulare were recovered from 27 locations. The two groups comprised 23 and 14 P. irregulare isolates which differed by $2 \mathrm{bp}$. However, there was no difference in pathogenicity (data not shown) between the two possible genotypes. In addition, the sequences of each genotype were identical to isolates of $P$. irregulare sensu stricto used by Garzon et al. (12). Therefore, all isolates were referred to as $P$. irregulare rather than two different genotypes until additional phylogenetic studies can be completed.

The DC-PCR amplicon for 13 P. ultimum var. sporangiiferum and 12 isolates of P. ultimum var. ultimum were identical for all isolates of the respective variety. In addition, the sequence of the P. ultimum var. sporangiiferum isolates was identical to the extype strain used in the original species description, and the sequence of the $P$. ultimum var. ultimum isolates were identical to the strain used for description in the monograph of van der PlaatsNiterink (46). Within just the 266-bp region sequenced for this study, there were 11 base pair differences as well as 5 insertions in $P$. ultimum var. sporangiiferum compared to $P$. ultimum var. ultimum. These data, sequence divergence as well as distribution in Ohio, suggest that the two varieties of $P$. ultimum may be distinct species. More isolates of each variety are now available for further phylogenetic and morphological studies to determine their true relationship.

There was no significant difference between the species which were isolated from the two soybean cultivars and the one corn hybrid. The one exception was $P$. arrhenomanes, which was only isolated from corn seedlings. Given this, the data for the soybean and corn were lumped for further analyses. Disease incidence across all baited locations was 20 to $82 \%$ with a mean of $50 \%$. Locations with high and low levels of disease incidence were evenly distributed across and within regions. This indicated that the sampling strategy was able to provide a range of soil samples having low, moderate, and high levels of disease, and that the sampling strategy was not biased by sampling only fields with high levels of inoculum. The range of incidence scores also indicated that the baiting procedure was an effective method for evaluating the inoculum potential of field soil in a growth chamber setting.

Nine different soil classes, based on textural analysis, were identified in the corn and soybean production region of Ohio, including clay, clay loam, loam, silty clay, silty clay loam, silt loam, sandy clay loam, and sandy loam. Clay content was 8 to $61 \%$ with a mean of $32 \%$. Clay loam and clay were the two most abundant soil classes, representing 37.5 and $22.5 \%$ of the locations, respectively. There was a wide range of variability for most soil variables. As a result, five locations were identified as outliers and excluded from the analysis due to either very low or very high levels of at least 3 of the 11 soil variables. There was a significant $(P=0.05)$ effect of soil class on disease incidence, with soils in the high silt soil class having the highest levels of disease and soils in the clay and clay loam soil classes having lower levels of disease (Table 1). There was no significant difference in disease incidence between the five soil regions in Ohio. In contrast, there was a significant $(P=0.05)$ difference in species diversity between soil regions (Table 2) and no significant difference between soil classes.

All 11 soil properties were included in the initial principal component analysis, but only $\mathrm{Ca}, \mathrm{Mg}, \mathrm{CEC}$, OM, percent sand, and percent silt had loading factors $>0.40$ in either of the first two principal components (Table 3). The first and second principal components represented 60 and $27 \%$ of the variability between locations, respectively. In principal component $1, \mathrm{Ca}, \mathrm{CEC}, \mathrm{Mg}$, and $\mathrm{OM}$ all had positive loading factors and percent sand and percent silt both had negative but small loading factors. There was a significant $(P=0.03)$ negative correlation $(-0.24)$ observed between principal component 1 and disease incidence, and a significant $(P=0.05)$ positive correlation $(0.35)$ between principal component 1 and species diversity. The relationships between principal component 2 and disease incidence and species diversity were not significant.

Species richness and abundance varied among locations. Species richness was 2 to 9 species and the average and median richness were 5.15 and 5.00, respectively. P. irregulare was the most abundant species, with 2,157 isolates recovered, which was

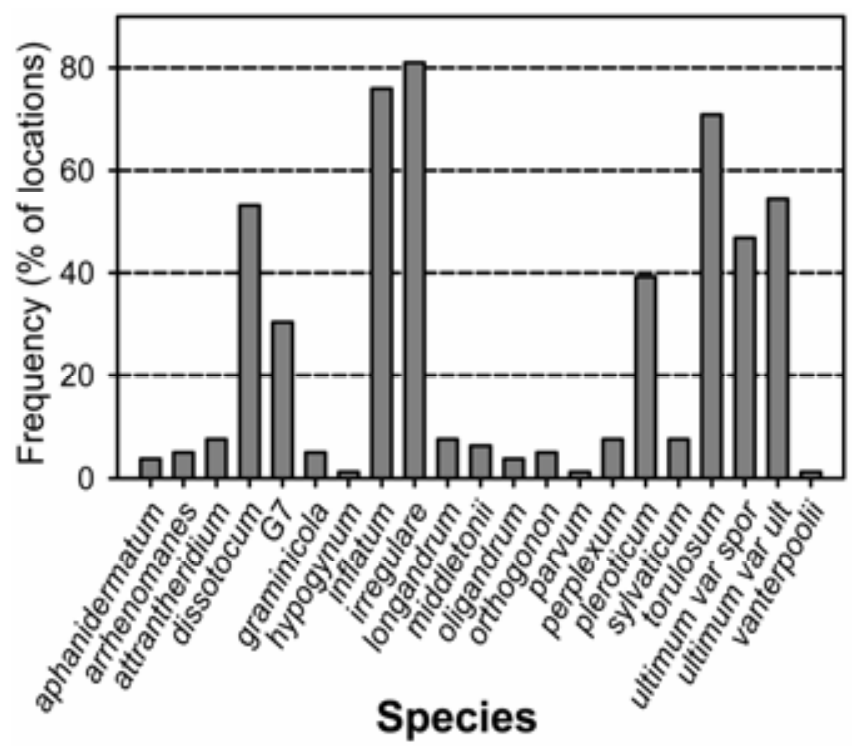

Fig. 3. Frequency of recovery of each species of Pythium from 83 of 88 locations in the corn and soybean growing region of Ohio. The frequency of occurrence of each species was calculated as the number of sites that contained that species/total number of sites $\times 100$. 
over twice as many isolates as the second most abundant species, $P$. inflatum (996 isolates). The species abundance distribution across the entire study area was indicative of a log-normal model $\left(F_{1,20}=120.6, P<0.001\right)$, where a few species represented the majority of the isolates, with many more rare species representing a few isolates per location (Fig. 4). P. irregulare, $P$. inflatum, $P$. ultimum var. ultimum, $P$. ultimum var. sporangiiferum, $P$. torulosum, and $P$. dissotocum composed $90 \%$ of all isolates recovered, while the remaining 15 species represented only $10 \%$ of the isolates recovered.

Species diversity scores $\left(\mathrm{H}^{\prime}\right)$ ranged from a high of 2.20 to a low of 0.04 , with a mean of 1.16 and a standard deviation of 0.54 . In the regression analysis, $\mathrm{pH}, \mathrm{Ca}, \mathrm{Mg}, \mathrm{CEC}$, and field capacity all had a significant $(P<0.05)$ positive linear relationship with species diversity. However, none of the five variables had an $R^{2}$ value $>0.10$, indicating none of the individual variables accounted for $>10 \%$ of the variability in species diversity. Disease incidence also had a significant $(P=0.04)$ negative linear relationship with species diversity. Field capacity was the only soil property that had a significant $(P=0.04)$ correlation with species diversity in the Spearman correlation analysis (Table 4 ). Soil variables were also evaluated to determine whether there was any correlation between individual properties and disease incidence. In the Spearman correlation analysis, the soil properties Ca, CEC, and OM had significant $(P<0.05)$ negative correlations with disease incidence (Table 4). Although there were notable and significant correlations with individual soil properties and disease incidence, the regression analysis indicated that only $\mathrm{Ca}$ and $\mathrm{CEC}$ had a significant $(P<0.01)$ negative linear relationship with disease incidence. The $R^{2}$ values for Ca and CEC were 11 and $10 \%$, respectively. The low $R^{2}$ values were a result of several outliers and distributed around the best-fit line, as well as unexplained variability, which indicated a poor fit in relation to disease incidence for any of the individual soil properties.

The clay and clay loam soil classes had the lowest mean disease incidence, but there were several individual locations that had high levels of disease ( $>60 \%)$, and the amount of $\mathrm{Ca}, \mathrm{Mg}$, $\mathrm{OM}$, and CEC ranged widely between locations in these two soil classes. When analyzing locations from the clay and clay loam soil classes, a similar trend was observed concerning the relationship between disease incidence and soil properties. In the principal component analysis, only $\mathrm{Ca}, \mathrm{Mg}$, OM, and $\mathrm{CEC}$ had loading factors greater than the absolute value of 0.4 in the first principal component, and percent sand and percent silt had loading factors greater than the absolute value of 0.6 in principal component 2

TABLE 3. Principal component (PC) loadings of soil properties that significantly contributed to differences in disease incidence of 83 of the 88 locations sampled from the corn and soybean production region of $\mathrm{Ohio}^{\mathrm{y}}$

\begin{tabular}{lcc}
\hline Soil property $^{z}$ & PC 1 (60\%) & PC 2 (27\%) \\
\hline Calcium (Ca) & 0.49 & 0.07 \\
Magnesium (Mg) & 0.47 & -0.09 \\
Cation exchange capacity (CEC) & 0.51 & 0.11 \\
Organic matter (OM) & 0.48 & 0.08 \\
Percent sand & -0.19 & 0.66 \\
Percent silt & -0.06 & -0.72 \\
\hline
\end{tabular}

${ }^{y}$ Loading values greater than, or equal to, the absolute value of 0.35 indicate significant interrelatedness. A large positive or negative correlation coefficient indicates the importance of a soil property on the differences among locations.

${ }^{z}$ Calcium and magnesium were measured as $\mu \mathrm{g} / \mathrm{g}$, CEC was measured as $\mathrm{meq} / 100 \mathrm{~g}$, and $\mathrm{OM}$ was measured as the percent weight loss on ignition.

TABLE 1. Means of soil chemical and physical properties from 83 of the 88 locations sampled in Ohio

\begin{tabular}{|c|c|c|c|c|c|c|c|c|c|c|c|c|c|c|}
\hline \multirow[b]{2}{*}{ Soil class ${ }^{\mathrm{w}}$} & \multirow[b]{2}{*}{$N$} & \multirow[b]{2}{*}{$\mathrm{DI}^{* \mathrm{x}}$} & \multirow[b]{2}{*}{$\mathrm{H}^{\prime y}$} & \multicolumn{11}{|c|}{ Soil properties ${ }^{\mathrm{z}}$} \\
\hline & & & & $\mathrm{pH}$ & $\mathrm{P}$ & $\mathrm{K}^{*}$ & $\mathrm{Ca}^{* * * *}$ & $\mathrm{Mg} * * *$ & CEC $* * *$ & $\mathrm{OM}^{* *}$ & Sand $* * *$ & Clay*** & Silt*** & $\mathrm{FC}^{* *}$ \\
\hline High silt & 10 & $63 \mathrm{a}$ & $1.21 \mathrm{a}$ & $6.4 \mathrm{ab}$ & $68.5 \mathrm{a}$ & $210.1 \mathrm{a}$ & $1,762.1 \mathrm{~b}$ & $348.4 \mathrm{~b}$ & $14.6 \mathrm{~b}$ & $3.8 \mathrm{a}$ & $19.5 \mathrm{~d}$ & $28.8 \mathrm{bc}$ & $51.6 \mathrm{a}$ & $21.6 \mathrm{a}$ \\
\hline High sand & 8 & $59 \mathrm{ab}$ & $0.97 \mathrm{a}$ & $6.0 \mathrm{~b}$ & $62.8 \mathrm{ab}$ & $134.9 \mathrm{~b}$ & $1,080.5 \mathrm{c}$ & $183.3 \mathrm{~d}$ & $10.1 \mathrm{c}$ & $2.6 \mathrm{c}$ & $53.1 \mathrm{a}$ & $24.0 \mathrm{c}$ & $23.0 \mathrm{~d}$ & $14.9 \mathrm{~d}$ \\
\hline Clay loam & 31 & $48 \mathrm{bc}$ & $1.24 \mathrm{a}$ & $6.5 \mathrm{a}$ & $44.9 \mathrm{ab}$ & $192.2 \mathrm{a}$ & $1,988.4 \mathrm{~b}$ & $333.3 \mathrm{bc}$ & $15.4 \mathrm{~b}$ & $3.4 \mathrm{ab}$ & $32.0 \mathrm{~b}$ & $33.2 \mathrm{~b}$ & $35.1 \mathrm{c}$ & $18.8 \mathrm{bc}$ \\
\hline Clay & 18 & $44 \mathrm{c}$ & $1.22 \mathrm{a}$ & $6.4 a b$ & $40.6 \mathrm{~b}$ & $195.6 \mathrm{a}$ & $2,667.7 \mathrm{a}$ & $507.3 \mathrm{a}$ & $21.9 \mathrm{a}$ & $4.1 \mathrm{a}$ & $24.2 \mathrm{~cd}$ & $45.3 \mathrm{a}$ & $30.4 \mathrm{c}$ & $20.7 \mathrm{ab}$ \\
\hline
\end{tabular}

${ }^{v}$ Soil collected at each location was classified based on soil texture, measured as the percent sand, silt, and clay, using the hydrometer method. Values in a column followed by the same letter are not significantly different, according to Fishers protected least significant difference $(P<0.05)$; *, **, and $* * *$ indicate a significant difference between soil classes at $P<0.05,0.01$, and 0.001, respectively. Soil texture was classified according to the United States Department of Agriculture guide.

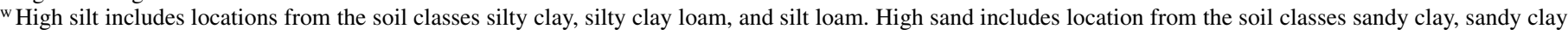
loam, and sandy loam.

${ }^{x}$ Disease incidence (DI) was calculated for each location as the number of infected plant/total number of plants sampled $\times 100$.

${ }^{y}$ Species diversity $\left(\mathrm{H}^{\prime}\right)$ was measured using the Shannon index. Each location was assigned a single species diversity score $\left(\mathrm{H}^{\prime}\right)$ and a mean was calculated for each soil class.

${ }^{z}$ Phosphorus, potassium, calcium, and magnesium were measured as $\mu \mathrm{g} / \mathrm{g}$. Cation exchange capacity (CEC) was measured as meq/100 g. Organic matter (OM) was measured as the percent weight loss on ignition. Field capacity (FC) was measured as the percent water at field capacity.

TABLE 2. Means of soil chemical and physical properties from the five major soil regions where corn and soybean are grown in Ohio

\begin{tabular}{|c|c|c|c|c|c|c|c|c|c|c|c|c|c|c|}
\hline \multirow[b]{2}{*}{ Region $^{\mathrm{w}}$} & \multirow[b]{2}{*}{$N$} & \multirow[b]{2}{*}{$\mathrm{DI}^{\mathrm{x}}$} & \multirow[b]{2}{*}{$\mathrm{H}^{\prime} * \mathrm{y}$} & \multicolumn{11}{|c|}{ Soil properties ${ }^{\mathrm{z}}$} \\
\hline & & & & $\mathrm{pH}$ & $\mathrm{P}$ & $\mathrm{K}^{*}$ & $\mathrm{Ca}^{* *}$ & $\mathrm{Mg}^{*}$ & $\mathrm{CEC}^{* *}$ & $\mathrm{OM}$ & Sand ${ }^{* *}$ & Clay* & Silt*** & $\mathrm{FC}^{*}$ \\
\hline North & 19 & $54.6 \mathrm{a}$ & $1.18 \mathrm{ab}$ & $6.3 \mathrm{ab}$ & $46.2 \mathrm{a}$ & $197.3 \mathrm{a}$ & $2,194 \mathrm{a}$ & $351.8 \mathrm{ab}$ & $16.7 \mathrm{a}$ & $4.36 \mathrm{a}$ & $39.0 \mathrm{a}$ & $34.3 \mathrm{ab}$ & $26.6 \mathrm{c}$ & $19.7 \mathrm{ab}$ \\
\hline Northcentral & 24 & $46.5 \mathrm{a}$ & $1.37 \mathrm{a}$ & $6.44 \mathrm{a}$ & $43.5 \mathrm{a}$ & $175.2 \mathrm{ab}$ & $2,120 \mathrm{ab}$ & $363.1 \mathrm{a}$ & $16.9 \mathrm{a}$ & $3.67 \mathrm{ab}$ & $27.5 \mathrm{bc}$ & $36.8 \mathrm{a}$ & $35.8 \mathrm{~b}$ & $20.6 \mathrm{a}$ \\
\hline Southcentral & 21 & $49.6 \mathrm{a}$ & $1.35 \mathrm{a}$ & $6.53 \mathrm{a}$ & $44.4 \mathrm{a}$ & $193.0 \mathrm{a}$ & $2,013 \mathrm{ab}$ & $389.42 \mathrm{a}$ & $15.8 \mathrm{ab}$ & $3.25 \mathrm{ab}$ & $26.5 \mathrm{c}$ & $32.8 \mathrm{abc}$ & $40.7 \mathrm{ab}$ & $18.0 \mathrm{~b}$ \\
\hline South & 11 & $54.7 \mathrm{a}$ & $0.86 \mathrm{~b}$ & $6.18 \mathrm{ab}$ & $42.1 \mathrm{a}$ & $130.0 \mathrm{~b}$ & $1,275 \mathrm{c}$ & $235.1 \mathrm{bc}$ & $10.3 \mathrm{c}$ & $2.80 \mathrm{~b}$ & $28.2 \mathrm{bc}$ & $26.5 \mathrm{c}$ & $45.2 \mathrm{a}$ & $18.0 \mathrm{~b}$ \\
\hline
\end{tabular}

${ }^{v}$ Values in a column followed by the same letter are not significantly different, according to Fishers protected least significant difference $(P<0.05) ; *, * *$, and $* * *$ indicate a significant difference between regions at $P<0.05,0.01$, and 0.001 , respectively.

${ }^{w}$ Soil regions were inferred from the soil region map assembled by the Ohio Department of Natural Resources.

x Disease incidence (DI) was calculated for each location as the number of infected plant/total number of plants sampled $\times 100$.

${ }^{y}$ Species diversity $\left(\mathrm{H}^{\prime}\right)$ was measured using the Shannon index. Each locations was assigned a single species diversity score $\left(\mathrm{H}^{\prime}\right)$ and a mean was calculated for each region.

${ }^{z}$ Phosphorus, potassium, calcium, and magnesium were measured as $\mu \mathrm{g} / \mathrm{g}$. Cation exchange capacity (CEC) was measured as meq/100 g. Organic matter (OM) was measured as the percent weight loss on ignition. Field capacity (FC) was measured as the percent water at field capacity. 
(Table 5). These results are very similar to those when 83 of the 88 locations were analyzed. A negative correlation was also observed between principal component 1 and disease incidence. When individual soil properties were evaluated significant $(P<$ $0.05)$, negative correlations between disease incidence and $\mathrm{Ca}$, $\mathrm{OM}$, and CEC were observed. Results of the regression analysis were also similar to those for the entire study area, because $\mathrm{Ca}$, $\mathrm{OM}$, and CEC individually had a significant $(P<0.05)$ linear relationship with disease incidence. The $R^{2}$ values for each of three variables were $<0.10$, indicating that none of the variables individually accounted for $>10 \%$ of the variation in disease incidence.
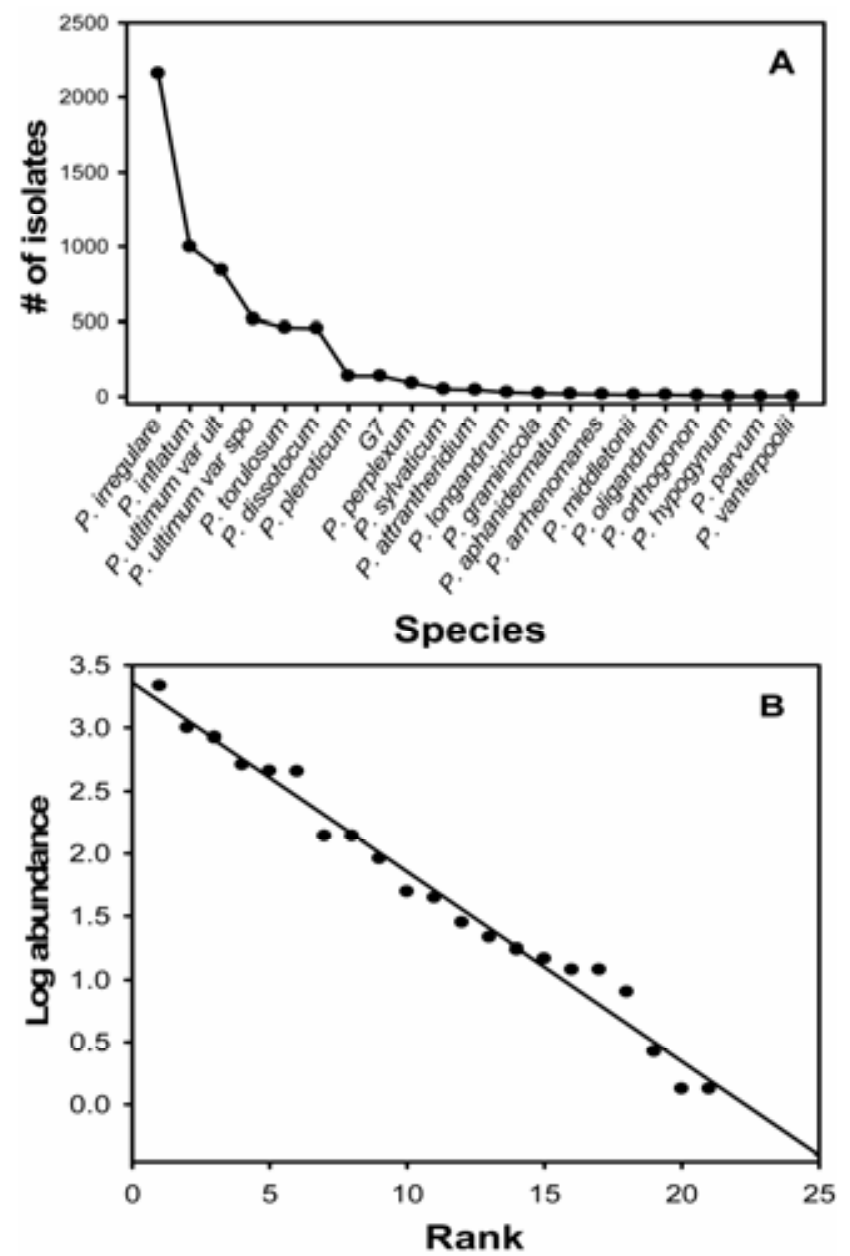

Fig. 4. Species abundance distribution of Pythium spp. recovered from 83 of 88 locations in the corn and soybean growing region of Ohio. Species abundance was measured as the number of isolates of each species recovered from each location. A, Abundance was plotted for each species and $\mathbf{B}$, the $\log$ transformation of abundance of each species was plotted against species according to rank, and showed a strong negative relationship that was indicative of a log normal model $\left(F_{1,20}=120.6, P<0.001\right)$.
Five major communities were grouped using cluster analysis and JI (Fig. 5). P. irregulare and P. inflatum were prevalent in the first three communities (abbreviations indicate species composition of the communities: $\mathrm{I}=P$. irregulare, $\mathrm{F}=P$. inflatum, $\mathrm{U}=$ $P$. ultimum var ultimum, $\mathrm{S}=P$. ultimum var. sporangiiferum, $\mathrm{D}=$ P. dissotocum, $\mathrm{T}=P$. torulosum, $\mathrm{P}=P$. pleroticum, and $\mathrm{G}=\mathrm{G} 7$ ). The first major community (IF) was characterized by the presence of $P$. irregulare and $P$. inflatum and very few other species. The second community (IFUDT) was characterized by $P$. irregulare and $P$. inflatum in the presence of $P$. ultimum var. ultimum, $P$. dissotocum, and $P$. torulosum. Community 3 (IFSDT) was characterized by $P$. irregulare and $P$. inflatum in association with $P$. ultimum var. sporangiiferum, $P$. dissotocum, and P. torulosum. The fourth community (IDPG) was notable for the absence of $P$. inflatum and the presence of $P$. pleroticum and G7 in association with $P$. irregulare and $P$. dissotocum. The fifth community (FUTPG) was characterized by the absence of $P$. irregulare and the presence $P$. inflatum, $P$. ultimum var. ultimum, $P$. pleroticum, G7, and $P$. torulosum commonly found together in this community. There was a significant $(P<0.05)$ difference in $\mathrm{pH}$, calcium, and magnesium content and OM between Pythium communities, and a highly significant $(P<0.001)$ difference in CEC between communities (Table 6). In addition, there was also a notable difference $(P<0.1)$ in clay and silt content between communities. Pythium community also had a significant $(P<0.05)$ effect on disease incidence, with community IF having the greatest disease incidence (Fig. 6). In contrast, the two communities with the lowest level of disease incidence were communities IDPG and FUPTG. These locations are notable because IDPG was the only community where $P$. inflatum was absent and FUPTG was the only community where $P$. irregulare was absent. Communities FUPTG and IFSDT had the highest mean species diversity scores (1.40) for all communities, and community IF had the lowest mean species diversity score $(0.66)$.

In the discriminate variable reduction step, soil variables $\mathrm{pH}, \mathrm{P}$, $\mathrm{Ca}, \mathrm{Mg}, \mathrm{OM}$, percent clay, and field capacity were determined to provide the most descriptive analysis of Pythium communities.

TABLE 5. Principal component (PC) loadings of soil properties that significantly contributed to differences in disease incidence from 48 locations sampled in the clay and clay loam soil classes ${ }^{y}$

\begin{tabular}{lcc}
\hline Soil property $^{z}$ & PC $1(56 \%)$ & PC 2 (27\%) \\
\hline Calcium (Ca) & 0.50 & 0.10 \\
Magnesium (Mg) & 0.46 & -0.16 \\
Cation exchange capacity (CEC) & 0.52 & 0.07 \\
Organic matter (OM) & 0.47 & 0.13 \\
Percent sand & -0.18 & 0.66 \\
Percent silt & 0.05 & -0.71 \\
\hline
\end{tabular}

${ }^{y}$ Loading values greater than, or equal to, the absolute value of 0.35 indicates significant interrelatedness. A large positive or negative correlation coe-

fficient indicates the importance of a soil property on the differences among locations.

${ }^{\mathrm{z}}$ Calcium and magnesium were measured as $\mu \mathrm{g} / \mathrm{g}$, CEC was measured as meq/100 g, and OM was measured as the percent weight loss on ignition.

TABLE 4. Correlation coefficients among soil properties, species diversity $\left(\mathrm{H}^{\prime}\right)$, and disease incidence (DI) from 83 of the 88 locations sampled in the corn and soybean production region of Ohio ${ }^{\mathrm{y}}$

\begin{tabular}{|c|c|c|c|c|c|c|c|c|c|c|c|c|}
\hline & \multirow[b]{2}{*}{ DI } & \multicolumn{11}{|c|}{ Soil properties ${ }^{\mathrm{z}}$} \\
\hline & & $\mathrm{pH}$ & Phosphorus & Potassium & Calcium & Magnesium & CEC & $\mathrm{OM}$ & Sand $(\%)$ & Clay (\%) & Silt (\%) & $\mathrm{FC}$ \\
\hline $\mathrm{H}^{\prime}$ & $\begin{array}{c}-0.22 \\
(0.04)\end{array}$ & $\begin{array}{c}0.21 \\
(0.06)\end{array}$ & $\begin{array}{c}-0.11 \\
(0.34)\end{array}$ & $\begin{array}{c}0.14 \\
(0.2)\end{array}$ & $\begin{array}{l}0.2 \\
(0.07)\end{array}$ & $\begin{array}{c}0.19 \\
(0.18)\end{array}$ & $\begin{array}{c}0.18 \\
(0.18)\end{array}$ & $\begin{array}{c}0.12 \\
(0.1)\end{array}$ & $\begin{array}{c}0.09 \\
(0.77)\end{array}$ & $\begin{array}{c}0.29 \\
(0.12)\end{array}$ & $\begin{array}{c}-0.02 \\
(0.89)\end{array}$ & $\begin{array}{c}0.22 \\
(0.04)\end{array}$ \\
\hline
\end{tabular}

y Spearman correlation coefficient resulted in positive and negative correlation coefficients, with probability values in parenthesis. Species diversity $\left(\mathrm{H}^{\prime}\right)$ was measured using the Shannon index. Each locations was assigned a single species diversity score $\left(\mathrm{H}^{\prime}\right)$.

${ }^{\mathrm{z}}$ Phosphorus, potassium, calcium, and magnesium were measured as $\mu \mathrm{g} / \mathrm{g}$. Cation exchange capacity (CEC) was measured as meq/100 g. Organic matter (OM) measured as the percent weight loss on ignition. Field capacity (FC) was measured as the percent water at field capacity. 
These variables were then used in the CDA. Two significant $(P<$ 0.0001 ) canonical discriminant functions were derived with the first function, accounting for $80 \%$ of the explained variance. The first function separated communities FUTPG, IFSDT, IFUDT, and IDPG from one another (Fig. 7) and the second function separated community IF from the other four communities (Fig. 7). Canonical correlation between soil variables and the first and second canonical discriminant functions were 0.94 and 0.73 , respectively.

In the first canonical discriminant function, soil variables $\mathrm{pH}$, $\mathrm{Ca}, \mathrm{Mg}$, and field capacity had standardized canonical coefficients greater than the absolute value of 0.3 , a level considered significant for interpretation (Table 7). The positive sign of the standardized coefficients for $\mathrm{Ca}, \mathrm{Mg}$, and field capacity suggests a positive contribution to the discrimination power of the first canonical discriminant function, in contrast to $\mathrm{pH}$, which had a negative standardized canonical coefficient. Soil properties $\mathrm{pH}, \mathrm{P}$, $\mathrm{Mg}, \mathrm{OM}$, percent clay, and field capacity had standardized canonical coefficients with absolute values $>0.3$ (Table 7). Phosphorus, OM, percent clay, and field capacity had positive standardized canonical coefficients, indicating a positive contribution to the discrimination power of the second canonical discriminant function, in contrast to $\mathrm{pH}$ and $\mathrm{Mg}$, which had negative standardize canonical coefficients.

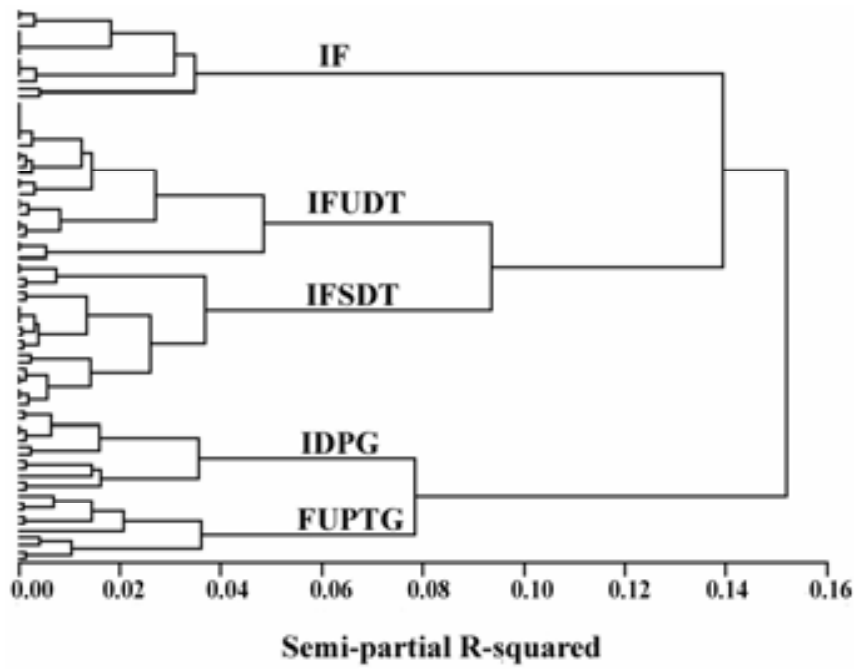

Fig. 5. Cluster analysis of locations based on the presence of Pythium spp. at each location and pairwise comparisons based on Jaccard's similarity coefficient. The ward's minimum variance method was used to construct the dendogram. $\mathrm{I}=$ Pythium irregulare, $\mathrm{F}=P$. inflatum, $\mathrm{U}=P$. ultimum var. ultimum, $\mathrm{S}=P$. ultimum var. sporangiiferum, $\mathrm{D}=P$. dissotocum, $\mathrm{T}=P$. torulosum, $\mathrm{P}=$ P. pleroticum, and $\mathrm{G}=\mathrm{G} 7$.
The soil variables $\mathrm{Ca}, \mathrm{Mg}$, and field capacity had the largest coefficients of correlation between the first canonical discriminant function, indicating that these variables were the most significant discriminators (coefficient of correlation >0.90) (Table 7). However, OM and percent clay also had significant positive coefficients of correlation $(>0.30)$. For the second canonical discriminant function, variables $\mathrm{pH}, \mathrm{Mg}$, and field capacity had significant coefficients of correlation $(>|0.30|)$ with the second canonical discriminant function (Table 7). The correlation between the second canonical discriminant function and $\mathrm{pH}$ and $\mathrm{Mg}$ was negative whereas the correlation with field capacity was positive.

\section{DISCUSSION}

This study surveyed 88 locations in Ohio's soybean and corn production region to determine which Pythium spp. predominated and which soil chemical and physical properties were correlated with the presence and distribution of these species. From this

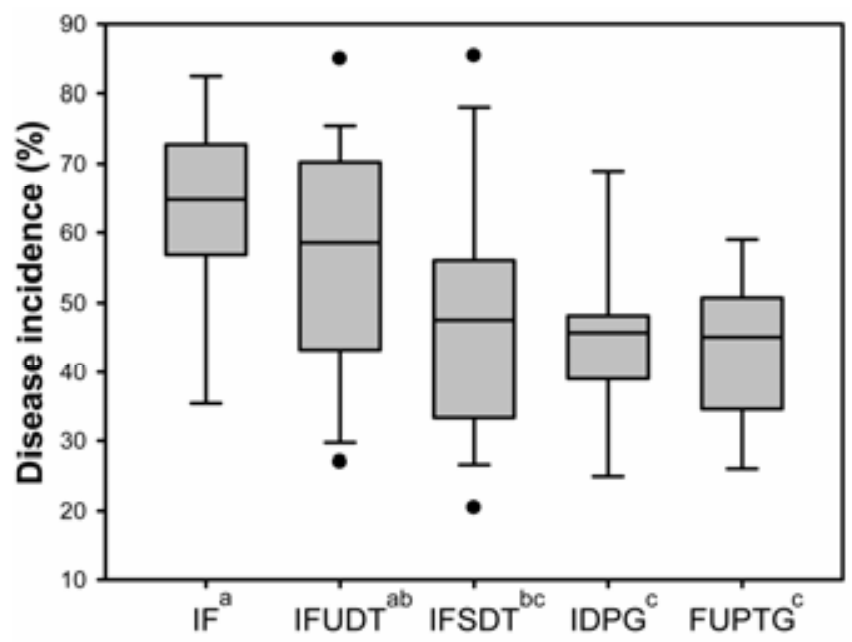

\section{Pythium communities}

Fig. 6. Box plot of the range of disease incidence scores for locations within the five Pythium communities in Ohio. Boxes represent the median (middle bar) and interquartile range (IQR) of disease incidence scores for each community. Additionally, vertical bars extending from boxes represent $1.5^{*}(\mathrm{IQR})$, and dots outside the vertical lines were considered outliers. Abbreviations indicate species composition of the communities: $\mathrm{I}=$ Pythium irregulare, $\mathrm{F}=$ P. inflatum, $\mathrm{U}=P$. ultimum var. ultimum, $\mathrm{S}=P$. ultimum var. sporangiiferum, $\mathrm{D}=P$. dissotocum, $\mathrm{T}=P$. torulosum, $\mathrm{P}=P$. pleroticum, and $\mathrm{G}=\mathrm{G} 7$. There was a significant $(P<0.05)$ effect of community on disease incidence. Communities followed by the same letter were not significantly different according to Fishers protected least significant difference $(P<0.05)$.

TABLE 6. Classification of soil chemical and physical properties from Pythium communities assembled from 83 of the 88 locations sampled in the corn and soybean production region of $\mathrm{Ohio}^{\mathrm{x}}$

\begin{tabular}{lcccccccccccc}
\hline & & \multicolumn{10}{c}{ Soil properties $^{\mathrm{z}}$} \\
\cline { 3 - 12 } Community $^{\mathrm{y}}$ & $N$ & $\mathrm{pH}$ & $\mathrm{P}$ & \multicolumn{1}{c}{$\mathrm{Ca}^{* *}$} & $\mathrm{~K}$ & $\mathrm{Mg}^{* *}$ & $\mathrm{CEC}^{* *}$ & $\mathrm{OM}^{*}$ & Sand & Clay & Silt & FC \\
\hline IF & 14 & $6.02 \mathrm{~b}$ & $55.13 \mathrm{a}$ & $1,515.4 \mathrm{c}$ & $174.7 \mathrm{a}$ & $234.2 \mathrm{c}$ & $13.02 \mathrm{c}$ & $3.09 \mathrm{~b}$ & $32.83 \mathrm{a}$ & $29.29 \mathrm{~b}$ & $37.87 \mathrm{ab}$ & $17.74 \mathrm{a}$ \\
IFUDT & 23 & $6.43 \mathrm{ab}$ & $51.69 \mathrm{a}$ & $1,796.3 \mathrm{bc}$ & $189.1 \mathrm{a}$ & $308.1 \mathrm{bc}$ & $13.90 \mathrm{bc}$ & $3.29 \mathrm{~b}$ & $30.31 \mathrm{a}$ & $32.02 \mathrm{ab}$ & $37.67 \mathrm{ab}$ & $20.30 \mathrm{a}$ \\
IFSDT & 21 & $6.36 \mathrm{ab}$ & $50.26 \mathrm{a}$ & $2,439.7 \mathrm{a}$ & $190.2 \mathrm{a}$ & $416.58 \mathrm{ab}$ & $19.47 \mathrm{a}$ & $4.11 \mathrm{a}$ & $30.77 \mathrm{a}$ & $37.64 \mathrm{a}$ & $31.58 \mathrm{~b}$ & $19.40 \mathrm{a}$ \\
IDPG & 14 & $6.22 \mathrm{~b}$ & $54.71 \mathrm{a}$ & $1,835.1 \mathrm{bc}$ & $192.2 \mathrm{a}$ & $304.4 \mathrm{bc}$ & $15.47 \mathrm{abc}$ & $3.20 \mathrm{~b}$ & $31.38 \mathrm{a}$ & $34.27 \mathrm{ab}$ & $35.31 \mathrm{ab}$ & $19.08 \mathrm{a}$ \\
FUPTG & 11 & $6.79 \mathrm{a}$ & $36.15 \mathrm{a}$ & $2,290.6 \mathrm{ab}$ & $149.2 \mathrm{a}$ & $478.4 \mathrm{a}$ & $17.53 \mathrm{ab}$ & $3.45 \mathrm{ab}$ & $25.07 \mathrm{a}$ & $31.29 \mathrm{ab}$ & $43.64 \mathrm{a}$ & $18.60 \mathrm{a}$ \\
\hline
\end{tabular}

${ }^{\mathrm{x}}$ Communities were groups of locations with similar species composition as a result of a hierarchical cluster analysis using the Jaccard similarity coefficient. Values in a column followed by the same letter are not significantly different, according to Fishers protected least significant difference $(P<0.05)$; $* * *$, and $* * *$ indicate a significant difference between communities at $P<0.05,0.01$, and 0.001 , respectively.

${ }^{y}$ Abbreviations indicate species composition of the communities: $\mathrm{I}=$ Pythium irregulare, $\mathrm{F}=P$. inflatum, $\mathrm{U}=P$. ultimum var ultimum, $\mathrm{S}=P$. ultimum var. sporangiiferum, $\mathrm{D}=P$. dissotocum, $\mathrm{T}=P$. torulosum, $\mathrm{P}=$ P. pleroticum, and $\mathrm{G}=\mathrm{G} 7$.

${ }^{\mathrm{z}}$ Phosphorus, potassium, calcium, and magnesium were measured as $\mu \mathrm{g} / \mathrm{g}$. Cation exchange capacity (CEC) was measured as meq/100 g. Organic matter (OM) was measured as the percent weight loss on ignition. Field capacity (FC) was measured as the percent water at field capacity. 
survey, $P$. irregulare was the most frequently recovered species and the most abundant species present. Previous studies showed the importance of $P$. irregulare in relation to early-season disease of corn and soybean in three fields in Ohio (11). This is similar to the other surveys of fungi associated with soybean seedling disease in Iowa (37), root diseases in continuous double-crop corn in Georgia (41), and red root rot of corn in combination with Phoma terrestris and Fusarium acuminatum (28). Pythium irregulare was also frequently recovered in wheat fields in the Pacific Northwest (7) and southern Australia (31). The second most frequently recovered species was $P$. inflatum, and the only previous report of this species in North America was from both corn and soybean in Ohio (3). P. inflatum was recovered from tree species in the Bavarian Alps (30), soil and water samples from Africa (32), and as a stalk rot pathogen of corn in China (47). However, work by Rao et al. (36) on root rot of corn in Ohio noted the recovery of a group of isolates with a description similar to that of P. inflatum.

P. ultimum var. ultimum, $P$. ultimum var. sporangiiferum, $P$. torulosum, and $P$. dissotocum were recovered from $>40 \%$ of the locations. P. ultimum was reported as being an important pathogen of soybean seed and seedlings in Minnesota (4) and Iowa $(37,48)$, on the soybean cv. Essex in Virginia $(13)$, and a pathogen of both corn and soybean in Iowa (49) and Ohio (3). P. ultimum was also observed to have an important role in seedling disease of soybean in response to flooding in Arkansas (20,21). P. torulosum and $P$. dissotocum were frequently recovered from diseased tissue of corn and soybean $(3,48)$ but usually had only a low or moderate level of pathogenicity.

Although the six previously mentioned species were predominant across the study area, a series of less frequently recovered species of Pythium were also observed. Similar results were reported from surveys of Pythium spp. isolated from wheat fields in Washington (33) and alfalfa seedlings in Missouri (26). Many of these rare species were not commonly reported from previous surveys of corn and soybean seed and seedling pathogens. This may be the result of the baiting procedure used in this study, because just the Pythium spp. present and active at relatively lower temperatures were recovered. Using nontreated corn and soybean seed as baits and isolating 10 days post-planting provided a view of how many Pythium spp. may be associated with germinating corn and soybean seed. Although the role of rare species is largely unknown, they may play a role in competing for resources with more pathogenic species because a negative correlation between disease incidence and species diversity was observed.

In the principal component analysis, the two component model with variables $\mathrm{Ca}, \mathrm{Mg}, \mathrm{CEC}, \mathrm{OM}$, percent sand, and percent silt

TABLE 7. Standardized canonical coefficients (SCC) and correlation coefficients (CCC) of discriminant canonical functions of soil variables selected by a stepwise discriminant analysis

\begin{tabular}{lrrrrr}
\hline & \multicolumn{3}{c}{ Canonical discriminant functions $^{\mathrm{y}}$} \\
\cline { 2 - 3 } \cline { 2 - 3 } \cline { 5 - 6 } Variable $^{\mathrm{z}}$ & \multicolumn{3}{c}{ SCC } & & \multicolumn{3}{c}{ CCC } \\
\cline { 2 - 3 } \cline { 5 - 6 } pH & -0.30 & -0.90 & & 0.25 & -0.63 \\
Phosphorus & 0.26 & 0.36 & & -0.08 & 0.11 \\
Calcium & 1.23 & 0.11 & & 0.91 & 0.01 \\
Magnesium & 1.45 & -1.22 & & 0.91 & -0.31 \\
OM & -0.15 & 0.57 & & 0.19 & 0.76 \\
Percent clay & -0.04 & 0.43 & & 0.18 & 0.61 \\
FC & 0.84 & 0.81 & & 0.71 & 0.30 \\
\hline
\end{tabular}

${ }^{y}$ SCC and CCC were used to evaluate the significance of soil chemical and physical properties in the canonical functions. Coefficients $>0.30$ were considered significant for interpretation.

${ }^{z}$ Phosphorus, calcium, and magnesium were measured as $\mu \mathrm{g} / \mathrm{g}$; organic matter $(\mathrm{OM})$ was measured as the percent weight loss on ignition; and field capacity (FC) was measured as the percent water at field capacity. adequately described the variability in disease incidence among 83 of the locations. OM serves as a nutrient source for Pythium spp. as primary colonizers, as well as many microorganisms that antagonize or compete with pathogenic Pythium spp. Increased soil OM positively influences several other soil factors, including soil structure, water-holding capacity, and microbial activity (46). Strong evidence for the role of OM in the suppression of Pythium disease have been reported from studies of horticultural crops in commercial planting mixes $(1,17,18)$ and tomato production in California (14). For agricultural production fields, the incorporation of plant residue left after harvest is one method for increasing $\mathrm{OM}$ content that serves as a source of organic carbon. Although no-till reduces soil erosion, occasional tillage provides soil mixing and aeration to promote the conversion of crop residue into stable soil $\mathrm{OM}$ and distribute the $\mathrm{OM}$ throughout the soil profile (35).

Calcium was also associated with both an increase in species diversity and a decrease in disease incidence caused by Pythium spp. It is important to note that both $\mathrm{Ca}$ and $\mathrm{Mg}$ content were very closely related to the CEC of the soil because these three variables had similar associations with both disease incidence and species diversity. Calcium concentrations were reported to increase production and aggregation of zoospores $(18,34,41)$. The influence of calcium on these different Pythium communities may be a result of the different reproduction and movement strategies of the six most commonly recovered species. $P$. inflatum, $P$. dissotocum, and $P$. torulosum all have filamentous sporangia and readily form zoospores when free water is available. In contrast, $P$. irregulare, $P$. ultimum var. ultimum, and $P$. ultimum var. sporangiiferum have either hyphal swellings or globose sporangia, which generally germinate directly and then move through the soil via mycelial growth $(29,44)$. However, Hill et al. (16) found that both direct and indirect germination of Phytophthora infestans sporangia was suppressed by a range of calciummodulating treatments, which may explain the negative association of calcium with disease incidence. Calcium, in the form of

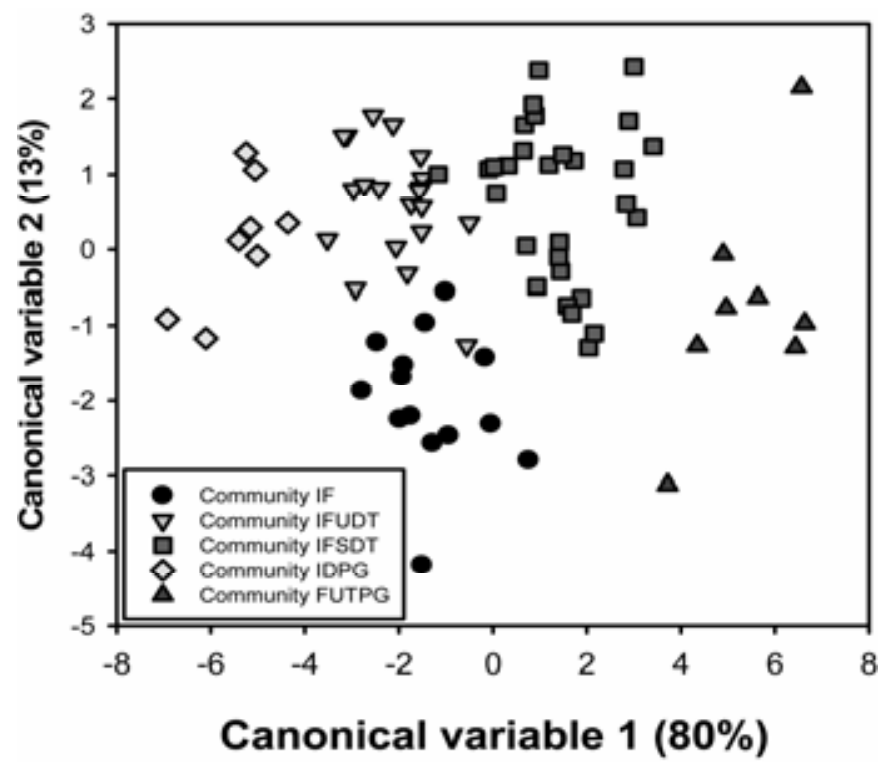

Fig. 7. Classification of 83 of the 88 soil samples recovered from Ohio into five groups, representing different communities of Pythium spp., based on the first and second canonical functions, from the canonical discriminant analysis. Abbreviations indicate species composition of the communities: $\mathrm{I}=$ Pythium irregulare, $\mathrm{F}=P$. inflatum, $\mathrm{U}=P$. ultimum var. ultimum, $\mathrm{S}=P$. ultimum var. sporangiiferum, $\mathrm{D}=P$. dissotocum, $\mathrm{T}=P$. torulosum, $\mathrm{P}=P$. pleroticum, and $\mathrm{G}=\mathrm{G} 7$. Stepwise multiple discriminant analysis and canonical discriminant analysis identified soil variables calcium, magnesium, organic matter, percent clay, and field capacity as contributing the most to separation of the five Pythium communities. 
lime, is commonly added to agricultural fields as calcium carbonate $\left(\mathrm{CaCO}_{3}\right)$ as a means of increasing the $\mathrm{pH}$ of the soil, and may be a viable option for increasing the calcium content of soils with low natural levels. Dolomite lime also generally includes magnesium carbonate, which may also benefit soils with low levels of magnesium.

The variation observed in soil chemical properties between soil regions and soil classes agrees with Cavigelli et al. (6), who observed that soil physical and chemical properties varied with soil type, soil drainage, and map location. In our study, soil regions did not provide a good prediction of disease incidence but differences were observed among the different soil classes. However, within a soil class, a large amount of variability in disease incidence was also observed. Based on the soil chemical and physical property analysis, soils within the clay and clay loam classes with higher $\mathrm{Ca}$ and $\mathrm{OM}$ content had lower levels of disease, perhaps reflecting the influence of these variables in suppressing disease caused by Pythium spp. regardless of soil particle size. These findings suggest that using large soil regions or even soil classes to predict disease incidence may not be possible due to the inherent variability across broad areas, and that probability of disease may only be assessed on a field by field basis because soil types and properties vary over relatively small areas in the corn and soybean production region of Ohio.

The higher incidence of root lesions and recovery of Pythium spp. from the high silt soil class compared with the clay and clay loam soil classes was unexpected because clay soils have smaller pore sizes and, therefore, promote water retention, predictably favoring the production and movement of zoospores produced by species of Pythium. In addition, high levels of disease are annually reported in fields with heavy clay soils. The locations in the high-silt soil class had a mean clay content of $29 \%$ and field capacity was not significantly different from clay and clay loam soils, indicating that the locations in the high silt soil class may be classified with the clay and clay loam locations as poorly to highly poorly drained. The high nutrient levels and increased amounts of OM of the clay soils may provide a much more competitive environment for species of Pythium. Also of interest are the eight locations in the high-sand soil class located in the northern region of the state occupying the former lake bed of Lake Erie. Soils in these locations are made up of lake deposits and lake-planed till which are underlain by shale and sandstone (5). These locations had higher than predicted levels of disease but, under field conditions, any substantial rain would lead to a flooding situation because water drainage is restricted through the shale and sandstone, creating a favorable environment for the proliferation and movement of zoospores produced by Pythium spp. Taken together, the majority of the locations in our study and across the corn and soybean production region are considered to be poorly drained to highly poorly drained, providing sufficient free water for the proliferation of Pythium spp. However, it requires less rainfall to create a flooding situation in clay and clay loam soils compared with the high-silt and high-sand soils.

The compositions of Pythium communities in corn and soybean fields and abiotic factors that affect them have rarely been evaluated on such a large geographic scale. Dick and Ali-Shtayeh (9) assessed Pythium spp. composition from 38 locations in farm and parklands in England, and found that cultivation practices had more of an effect than crop sequence. Paulitz and Adams (33) evaluated the composition and distribution of Pythium communities in 80 wheat fields of the Pacific Northwest and observed a correlation between Pythium communities and environmental factors. In their study, Pythium abappressorium, $P$. rostratum, $P$. debaryanum, and $P$. heterothallicum were the most frequently recovered species and, based on cluster analysis, six communities of Pythium spp. were defined. In this study of 83 corn and soybean fields in Ohio, CDA was successful at grouping locations into five Pythium communities based on soil properties. The three communities, in which $P$. irregulare and $P$. inflatum were prevalent, were plotted close to each other in the discriminate canonical analysis. Community IF, dominated by these two species and very few other species, was separated on the canonical variable 2 axis from the other four communities. Therefore, the ability of $P$. irregulare and $P$. inflatum to outcompete other species may increase as $\mathrm{pH}$ and magnesium increase and $\mathrm{OM}$, percent clay, and field capacity decrease. Community IF also had the highest level of disease incidence of any community. Locations in community FUTPG, lacking the presence of $P$. irregulare, were clearly separated from the other communities that contained $P$. irregulare. These locations had relatively high scores for canonical variable 1 , suggesting an inability of $P$. irregulare to compete as $\mathrm{Ca}$ and field capacity of a location increase and $\mathrm{pH}$ decreases. Community IDPG, which lacks $P$. inflatum, was in complete contrast to community FUTPG along canonical variable 1. Interestingly, these two communities had the lowest levels of disease incidence. The functions generated by the CDA in this study should enable the prediction of Pythium communities based on soil properties. Discriminant analysis was also used to evaluate how climatic factors such as rainfall and minimum and maximum air temperature affected severity of sorghum leaf blight in South Africa (14) and how agricultural and nonagricultural environments differentially influenced production of sporangia and zoospores of Phytophthora capsici, and to classify soil samples into agricultural and nonagricultural based on soil chemical properties and production of zoospores by $P$. capsici in soil extracts (39).

Knowledge of the community of Pythium spp. present in a location would be valuable information to producers in regards to the selection of seed treatment fungicides. Broders et al. (3) reported that Pythium inflatum, $P$. dissotocum, and $P$. torulosum were insensitive to mefenoxam but sensitive to the strobilurin fungicide azoxystrobin. In contrast, $P$. irregulare and $P$. ultimum var. ultimum were insensitive to azoxystrobin and sensitive to mefenoxam (3). Geographic, biotic, and abiotic variables all play an important role in forming species communities. In this study, Pythium communities and Pythium spp. diversity was examined from the corn and soybean production region of Ohio, and chemical and physical soil properties were evaluated for their association with Pythium communities, species diversity, and disease incidence. $P$. irregulare, being the most frequently recovered species, was most abundant in locations with low levels of calcium, magnesium, and OM that were poorly drained and had limited species diversity. CDA was able to demonstrate the influence of soil chemical and physical properties on species composition. The communities were assigned after the sampling process; therefore, it is inappropriate to establish a cause-andeffect relationship among communities and soil properties, even though significant correlations were observed for some variables. Therefore, further temporal studies will help to determine how Pythium communities change over time and what soil properties effect the formation of specific communities in a corn and soybean production field. In addition, sampling fields from a larger geographic area should enable the evaluation of the functions generated in the CDA to predict the Pythium community present in soil samples and determine whether other states in the corn and soybean production regions of the United States have similar Pythium communities.

\section{ACKNOWLEDGMENTS}

This project was supported in part by the OARDC Matching Grants Program (SEEDS), The OARDC Graduate Research Enhancement Grant Program, Syngenta Crop Protection Seed Improvement Grant, Pioneer Crop Management Research Awards Program, and Ohio's Soybean Producers' check-off dollars through the Ohio Soybean Council. We thank S. A. Berry and F. Cruz for technical assistance, all the county extension educators and producers who provided access to fields for sampling, and 
the OARDC Molecular Cellular Imaging Center and Ohio Bioproducts Innovation Center for access to the MEGA-Gel apparatus as well as sequencing facilities.

\section{LITERATURE CITED}

1. Boehm, M. J., and Hoitink, H. A. J. 1992. Sustenance of microbial activity in potting mixes and its impact on severity of Pythium root rot of poinsettia. Phytopathology 82:259-264.

2. Broders, K. D., Lipps, P. E., Paul, P. A., and Dorrance, A. E. 2007. Characterization of Pythium spp. associated with corn and soybean seed and seedling disease in Ohio. Plant Dis. 91:727-735.

3. Broders, K. D., Lipps, P. E., and Dorrance, A. E. 2009. Pythium delawarii-A new species isolated from soybean in Ohio. Mycologia. 101:232-238.

4. Brown, G. E., and Kennedy, B. W. 1965. Pythium pre-emergence damping-off of soybean in Minnesota. Plant Dis. Rep. 49:646-647.

5. Camp, M. J. 2006. Roadside geology of Ohio. Mountain Press Publishing Co., Missoula, MT.

6. Cavigelli, M. A., Lengnick, L. L., Buyer, J. S., Fravel, D., Handoo, Z., McCarty, G., Millner, P., Sikora, L., Wright, S., Vinyard, B., and Rabenhorst, M. 2005. Landscape level variation in soil resources and microbial properties in a no-till corn field. Appl. Soil Ecol. 29:99-123.

7. Chamswrang, C., and Cook, R. J. 1985. Identification and comparative pathogenicity of Pythium species from wheat roots and wheat-field soils in the Pacific Northwest. Phytopathology 75:821-827.

8. Deep, I. W., and Lipps, P. E. 1996. Recovery of Pythium arrhenomanes and its virulence to corn. Crop Prot. 15:85-90.

9. Dick, M. W., and Ali-Shtayeh, M. S. 1986. Distribution and frequency of Pythium species in parkland and farmland soils. Trans. Br. Mycol. Soc. 86:49-62.

10. Dorrance, A. E., Berry, S. A., Anderson, T. R., and Meharg, C. 2008. Isolation, storage, pathotype characterization, and evaluation of resistance for Phytophthora sojae in soybean. Plant Heath Progress doi:10.1094/PHP-2004-0202-01-RS.

11. Dorrance, A. E., Berry, S. A., Bowen, P., and Lipps, P. E. 2004. Characterization of Pythium spp. from three Ohio fields for pathogenicity on corn and soybean and metalaxyl sensitivity. Plant Heath Progress doi:10.1094/PHP-2004-0202-01-RS

12. Garzon, C. D., Geiser, D. M., and Moorman, G. W. 2005. Amplified fragment length polymorphism analysis and internal transcribed spacer and coxII sequences reveal a species boundary within Pythium irregulare. Plant Dis. 95:1489-1498.

13. Griffin, G. J. 1990. Importance of Pythium ultimum in a disease syndrome of cv. Essex soybean. Can. J. Plant Pathol. 12:134-140.

14. Hennessy, G. G., Demailliano, W. A. J., and McLaren, C. G. 1990. Influence of primary weather variables on sorghum leaf-blight severity in Southern Africa. Phytopathology 80:943-945.

15. Higginbotham, R. W., Paulitz, T. C., and Kidwell, K. K. 2004. Virulence of Pythium species isolated from wheat fields in eastern Washington. Plant Dis. 88:1021-1026.

16. Hill, A. E., Grayson, D. E., and Deacon, J. W. 1998. Suppressed germination and early death of Phytophthora infestans sporangia caused by pectin, inorganic phosphate, ion chelators and calcium-modulating treatments. Eur. J. Plant Pathol. 104:367-376.

17. Hoitink, H. A. J., and Fahy, P. C. 1986. Basis for the control of soilborne plant pathogens with composts. Annu. Rev. Phytopathology 24:93-114.

18. Hoitink, H. A. J., and Boehm, M. J. 1999. Biocontrol within the context of soil microbial communities: A substrate-dependent phenomenon. Annu. Rev. Phytopathol. 37:427-446.

19. Khattree, R., and Naik, D. N. 2000. Multivariate data reduction and discrimination with SAS software. SAS Institute Inc., Cary, NC.

20. Kirkpatrick, M. T., Rothrock, C. S., Rupe, J. C., and Gbur, E. E. 2006. The effect of Pythium ultimum and soil flooding on two soybean cultivars. Plant Dis. 90:597-602.

21. Kirkpatrick, M. T., Rupe, J. C., and Rothrock, C. S. 2006. Soybean response to flooded soil conditions and the association with soilborne plant pathogenic genera. Plant Dis. 90:592-596.

22. Kong, P., Hong, C., Richardson, P. A., and Gallegly, M. E. 2003. Singlestrand-conformation polymorphism of ribosomal DNA for rapid species differentiation in genus Phytophthora. Fungal Genet. Biol. 39:238-249.

23. Kong, P., Richardson, P. A., and Hong, C. 2005. Direct colony PCR-SSCP for detection of multiple pythiaceous oomycetes in environmental samples. J. Microbiol. Methods 61:25-32.
24. Kong, P., Richardson, P. A., Moorman, G. W., and Hong, C. 2004. Singlestrand conformational polymorphism analysis of the ribosomal internal transcribed spacer 1 for rapid species identification within the genus Pythium. FEMS Microbiol. Lett. 240:229-236.

25. Krebs, C. J. 1999. Ecological Methodology. Benjamin Cummings, Menlo Park, CA.

26. Larkin, R. P., and Engish, J. T., and Mihail, J. D. 1995. Identification, distribution and comparative pathogenicity of Pythium spp. associated with alfalfa seedlings. Soil Biol. Biochem. 27:357-364.

27. Lipps, P. E., and Deep, I. W. 1991. Influence of tillage and crop rotation on yield, stalk rot, and recovery of Fusarium and Trichoderma spp. from corn. Plant Dis. 75:828-833.

28. Mao, W., Carroll, R. B., and Whittington, D. P. 1998. Association of Phoma terrestris, Pythium irregulare, and Fusarium acuminatum in causing red root rot of corn. Plant Dis. 82:337-342.

29. Martin, F. N., and Loper, J. E. 1999. Soilborne plant diseases caused by Pythium spp.: Ecology, epidemiology, and prospects for biological control. Crit. Rev. Plant Sci. 18:111-181.

30. Nechwatal, J., and Osswald, W. 2001. Comparative studies on the fine root status of healthy and declining spruce and beech trees in the Bavarian Alps and occurrence of Phytophthora and Pythium species. For. Pathol. 31:257-273.

31. Pankhurst, C. E., McDonald, H. J., and Hawke, B. G. 1995. Influence of tillage and crop rotation on the epidemiology of Pythium infections of wheat in red-brown earth of south Australia. Soil Biol. Biochem. 27:10651073.

32. Paul, B., Boutchet, P., and Bouchet, F. 1994. Some species of Pythium isolated from soil and water samples collected in Western Africa. Microbiol. Res. 149:217-222.

33. Paulitz, T. C., Adams, K. 2003. Composition and distribution of Pythium communities in wheat fields in Eastern Washington state. Phytopathology 93:867-873

34. Pielou, E. C. 1984. The interpretation of ecological data: A primer on classification and ordinations. John Wiley \& Sons, New York.

35. Quincke, J. A., Wortman, C. S., Mamo, M., Franti, T., and Drijber, R. A. 2007. Occasional tillage of no-till systems: Carbon dioxide flux and changes in total and labile soil organic carbon. Agron. J. 99:1158-1168

36. Rao, B., Schmitthenner, A. F., Caldwell, R., and Ellett, C. W. 1978. Prevalence and virulence of Pythium species associated with root rot of corn in poorly drained soil. Phytopathology 68:1557-1563.

37. Rizvi, S. S. A., and Yang, X. B. 1996. Fungi associated with soybean seedling disease in Iowa. Plant Dis. 80:57-60.

38. Sambrook, J., and Russell, D.W. 2001. Molecular Cloning: A Laboratory Manual. 3rd ed. Cold Spring Harbor Laboratory Press, Cold Spring Harbor, NY.

39. Sanogo, S. 2007. Asexual reproduction of Phytophthora capsici as affected by extracts from agricultural and nonagricultural soils. Phytopathology 97:873-878.

40. Schmitthenner, A. F., and Bhat, R. G. 1994. Useful Methods for Studying Phytophthora in the Laboratory, Plant Pathology, Ohio Agric. Res. Dev. Cent. Spec. Circ. 143.

41. Sumner, D. R., Gascho, F. J., Johnson, A. W., Hook, J. E., and Threadgill, D. E. 1990. Root diseases, populations of soil fungi, and yield decline in continuous double-crop corn. Plant Dis. 74:704-710.

42. Tan, K. H. 1996. Soil Sampling, Preparation, and Analysis. Marcel Dekker, Inc., New York.

43. Thompson, S. K. 1992. Sampling. John Wiley and Sons, New York

44. van der Plaats-Niterink, A .J. 1981. Monograph of the Genus Pythium. Vol. No. 21, Studies in Mycology. Centraalbureau voor Schimmelculture, Baarn, The Netherlands.

45. Waterhouse, G. M. 1967. Key to Pythium Pringsheim. Mycol. Pap. 109:115.

46. Weil, R. R., and Magdoff, F. 2004. Significance of soil organic matter to soil quality and health. In Soil Organic Matter in Sustainable Agriculture. F. Magdoff, and R. Wiel, eds. CRC Press, Boca Raton, FL.

47. Yang, D. E., Jin, D. M., Wang, B., Zhang, D. S., Nguyen, H. T., Zhang, C. L., and Chen, S. J. 2005. Characterization and mapping of Rpi1, a gene that confers dominant resistance to stalk rot in maize. Mol. Genet. Genomics 274:229-234.

48. Zhang, B. Q., and Yang, X. B. 2000. Pathogenicity of Pythium populations from corn-soybean rotation fields. Plant Dis. 84:94-99.

49. Zhang, B. Q., Chen, W. D., Yang, X. B. 1998. Occurrence of Pythium species in long-term maize and soybean monoculture and maize/soybean rotation. Mycol. Res. 12:1450-1452. 